\title{
Engineering Students as Science Teachers: A Case Study on Students' Motivation
}

\author{
http://dx.doi.org/10.3991/ijep.v4i3.3503 \\ A. Gero \\ Technion - Israel Institute of Technology, Haifa, Israel
}

\begin{abstract}
The program "Educational Clinic" was recently developed and implemented at the Technion - Israel Institute of Technology. This one year program is designed to train engineering students as teaching assistants in high schools in order to help high school pupils with mathematics and science. The study described in this paper tracked changes in students' motivation to participate in the program throughout the year. Data was collected by questionnaires and interviews. The findings reveal that alongside a fixed high level of extrinsic motivational factors, which reflect student satisfaction of improving their teaching skills, a considerable increase was found in the level of intrinsic motivational factors, which express the students' interest in the program.
\end{abstract}

Index Terms-Engineering education, motivation, outreach activities, science teaching.

\section{INTRODUCTION}

Due to the acute shortage of scientists and engineers [12], many universities offer programs which aim to increase high school pupils' interest in science and engineering and encourage them to develop a career in these fields. Some of the programs are set in the universities themselves, which high school pupils visit [3-4], while in others the activity is held in the high schools with the universities' representatives - professors and students. For instance, in the UK, faculty members teach a basic course in programming in high schools [5], and in Brazil, scholarship students demonstrate laboratory experiments in high schools [6].

Recently at the Technion - Israel Institute of Technology, a unique program entitled "Educational Clinic" has been developed and implemented. The program which lasts for one academic year is designed to train engineering students as teaching assistants in high schools, in order to help high school pupils with mathematics and science and increase their interest in higher education in these disciplines. The first part of the program provides theoretical knowledge regarding learning theories and teaching methods, and as part thereof the students experience teaching science in front of their peers. The second part of the program includes practical experience in teaching science at high schools in front of small groups of pupils. It is important to note that contrary to similar programs, as detailed above, the current program does not limit students to demonstrating experiments alone, but they may also teach theoretical subjects. In addition, they do not get a scholarship in return for their participation, but an academic score of three credit points including grading.

Thirteen students took part in the first class of the program, which was held in 2013 . The study described here tracked changes in students' motivation to participate in the program.

We begin the paper with a literature review on motivation and the self-determination theory. Next, we describe the program "Educational Clinic" and present the research goal and chosen methodology. Finally, after describing the findings, we discuss the conclusions and suggest directions for further research.

\section{THEORETICAL BACKGROUND}

Motivation is a driving force at activities directing, voluntarily and without coercion, for the investment of physical, mental and spiritual effort. According to Maehr [7] motivation is characterized by the following dimensions: direction - selecting the specific behavior from the variety of all the possibilities, intensity - the amount of resources invested in the selected behavior, and quality - how the individual feels about the selected behavior.

Theories of motivation attempt to trace the source of motivation and explain processes that drive the individual to behave as he/she does. Theories can be affiliated to the personality [8], behavioral [9], social-cognitive [10-11] and humanistic approaches. The humanistic approach, described below, emphasizes the importance of providing the needs of the individual and his/her tendency to selfactualization. Maslow's hierarchy of needs [12], is considered one of the most prominent representative of the humanistic approach, according to which innate human needs maintain a hierarchical relationship between them, so that while needs were not yet provided at a given level, needs at a higher level will not affect the motivation.

The self-determination theory [13-14] argues that a person has three innate needs: need for autonomy - the need to feel that the individual's behavior was not forced upon him/her, need for competence - the need to feel that the individual is capable to meet challenging goals, and need for relatedness - the need to be accepted and valued by others. Conditions supporting these needs foster high quality motivation. Deci et al. [13] describe the sources of motivation as a spectrum between intrinsic factors and extrinsic ones. Located at one end is the Intrinsic Motivation arising from interest and enjoyment. At the opposite end lies the Extrinsic Motivation which includes four types of regulation:

- Integrated regulation resulting from seeing the behavior as reflecting the identity of the individual;

- Identified regulation resulting from identifying the inherent value of the behavior. The behavior is a means allowing another activity which brings about interest and enjoyment, or alternatively, the behavior is of a moral value; 
- Introjected regulation which is caused by a need for ego enhancement [15] or a desire to fulfill the expectations of people important to the individual;

- External regulation deriving from hope for receiving a material reward, or alternatively, fear of punishment. This regulation is the only type of motivation recognized by supporters of the behavioral approach [9].

In addition, the theory defines a state of lack of motivation (Amotivation) in which the individual lacks the intention to act. Amotivation results from not feeling competent to do an activity [16] or not indentifying its value [17]. The theory claims that the more the motivation stems from intrinsic factors, the more its quality is high.

The self-determination theory in the educational context [18-19] serves as a theoretical framework in many studies dealing with motivation among pupils in schools [20-22] and students in universities [23-24]. For instance, Koh et al. [25] showed that simulation based learning among mechanical engineering students has provided the three needs discussed, and thus improved the intrinsic motivation. Additionally, Gero [26] found a significant improvement in the intrinsic motivation of electrical engineering students who took an introductory course that has fulfilled these needs. Since this theory has become a leading theory in educational motivation, it will be used to examine the motivation of students attending the program "Educational Clinic".

\section{PROGRAM DESCRIPTION}

The program "Educational Clinic" is as aforesaid, made up of two parts. The first part focuses on concise teacher training, which is provided during the winter semester as part of the academic course "Educational Clinic 1", of three weekly hours. The second part, which is mainly experiencing teaching in high schools, is held during the spring semester as part of the course "Educational Clinic $2 "$. The program is offered to all undergraduate students at the Technion.

The course "Educational Clinic 1" begins with a six weeks long theoretic chapter which deals with learning theories and teaching methods. The cognitive, affective and social aspects of learning are taught over the first three weeks. The following three weeks are dedicated to teaching objectives, teaching methods, and teaching evaluation. On the seventh week, a model lesson is held by the course faculty. The remaining weeks are dedicated to microteaching, as part of which each student gets to experience teaching a 45 minutes class in front of his/her course peers, on a subject of his/her choosing taken from the high school curriculum in mathematics or physics. The rest of the students actively participate in class, including asking questions, while at the same time filling out a suitable evaluation form. At the end of the class, a discussion is held with the teaching student, his/her course peers, and the faculty, at the end of which the student is asked to submit a reflection report. A weekly syllabus is given in Table I.

As part of the course "Educational Clinic 2", the students teach in high schools small groups of pupils, for three weekly hours. A variety of scientific subjects are taught with the guidance of a professional teacher. The students help high school pupils with difficulties and/or guide extracurricular activities for outstanding pupils, in- cluding tours of the Technion. It is important to note that the students are the ones to select the school and the subject, and they are not limited to the high school curriculum. Throughout the semester the course faculty holds guidance meetings with the students. During these meetings the students discuss experiences and jointly deal with difficulties.

TABLE I.

"EDUCATIONAL CliniC 1": WEEKLy SyLlabus

\begin{tabular}{|c|c|c|}
\hline Week & Subject & Details \\
\hline $1-3$ & Learning & $\begin{array}{l}\text { - Learning: definitions, factors influencing } \\
\text { learning } \\
\text { - Cognitive aspects of learning: definitions, } \\
\text { theories of cognitive development } \\
\text { - Motivation and learning: definitions, moti- } \\
\text { vation theories } \\
\text { - Social aspects of learning: social facilita- } \\
\text { tion, social loafing, conformity, stereotype } \\
\text { threat, self-fulfilling prophecy } \\
\text { - Learning theories: behavioral learning, } \\
\text { cognitive-behavioral learning, social learn- } \\
\text { ing } \\
\text { - Transfer of learning: definitions, taxono- } \\
\text { mies }\end{array}$ \\
\hline $4-6$ & Teaching & $\begin{array}{l}\text { - Teaching objectives: definitions, taxono- } \\
\text { mies } \\
\text { - Stage fright } \\
\text { - Teaching methods } \\
\text { - Teaching evaluation }\end{array}$ \\
\hline $7-14$ & Microteaching & $\begin{array}{l}\text { - Model lesson } \\
\text { - Microteaching and reflection }\end{array}$ \\
\hline
\end{tabular}

\section{RESEARCH GOAL}

The research goal was to track changes in the motivation of students attending the program "Educational Clinic". The following research question was derived from the research objective: Was there a change during the program in students' motivational factors? If so - what characterizes this change?

\section{Methodology}

The research population comprised of thirteen engineering students (two of which are female students) aged $20-$ 33 . The students were in their $3^{\text {rd }}-9^{\text {th }}$ semester of studies. Ten of them had some experience in teaching. As part of the program, the students taught at eight high schools in the north of Israel. The students taught mathematics, physics, chemistry, biology, and computer science to groups of pupils of the $8^{\text {th }}$ to $12^{\text {th }}$ grades, composed of two to twenty eight pupils.

In light of the small number of students who had taken part in the program, and since the study focused on characterizing change processes the students underwent during the program, we chose to use qualitative tools. The students were asked to fill out open questionnaires on three dates: a preliminary questionnaire at the beginning of the course "Educational Clinic 1" (Questionnaire 0), an intermediate questionnaire at the end of the course "Educational Clinic 1" (Questionnaire 1), and a final questionnaire at the end of the course "Educational Clinic 2" (Questionnaire 2). In addition, at the end of each course group interviews were held with the students. The questionnaires and interviews focused on the students' motivation to participate in the program. Students' answers were content ana- 
lyzed and categorized. The self-determination theory was used as a theoretical framework for the qualitative analysis.

\section{FINDINGS}

In the preliminary questionnaire (Questionnaire 0 ), the students were asked "Why did you choose to participate in the program?". Twelve of the respondents $(92 \%)$ gave practical reasons: "overcoming stage fright", "improving my self-confidence", and even "it helps with job interviews". One student only (8\%) mentioned interest as a factor for his participation in the program: "The subject of teaching is very interesting".

In the intermediate questionnaire (Questionnaire 1), which was filled out at the end of the "Educational Clinic 1 " course, the students were asked "What are your feelings having experienced microteaching?". All students (100\%) noted that it was an especially positive experience: "It was an exceptional experience", and "The experience I had is priceless". Excerpts from the interviews reveal that the positive experience was as a result of feeling able to successfully accomplish the challenge of teaching a class:

"I have experienced the real thing... it was really challenging... but I managed to do it!"

In the intermediate questionnaire the students were also asked "What is your opinion of the course?". All students $(100 \%)$ wrote the course was able to provide teaching skills: "The course is very important for any future engineer. It excellently prepares you to present projects and face an audience", and "It provides very necessary tools for all students and tutors at the Technion". Six of them $(46 \%)$ also noted the interest and enjoyment they had found in the course: "It is definitely the most interesting course I took during these studies" and "The main feeling I take from this is enjoyment".

In the final questionnaire (Questionnaire 2), which was filled out at the end of the "Educational Clinic 2" course, the students were asked about their considerations when choosing the high school in which they had taught, "Please specify your considerations in choosing the high school in which you taught". Seven students (54\%) noted they preferred teaching in the same high school they went to as pupils and to which they feel a sense of belonging: "I viewed this experience as closure and an opportunity to give back a little to the place where I grew up", and "This is the high school I had attended... this is my community and I can help it". Others wrote that they had chosen the high school according to the characteristics of the pupils who attend it "I felt comfortable standing in front of stronger pupils with a liking of the subject".

In reply to the question of "What do you think of the program?", all students (100\%) noted their positive impression of it and mentioned both the benefit they had gained therefrom: "I learned how to improve my teaching skills... it benefited me... skills I am taking with me to any project I may deal with in future in the field of teaching / training and marketing", and the interest and enjoyment they had experienced: "This is the most fun thing I have had since I started studying at the Technion (and I have been studying for many years)" and "The activity was very interesting for me... after the training and everything I went through with the class I felt I was giving to the pupils because I wanted to give and not because I had to".
Excerpts from the interviews reveal that the sense of autonomy had contributed to the enjoyment which characterized teaching at a high school:

"A really fun experience... there is no other place school or academic course - which gives you such a free hand as they do here... which lets you try and dare... make your own decisions regarding what to teach, how, and at what pace."

The sense of competence also contributed to the enjoyment:

"My self-confidence improved really rapidly... I felt wonderful that I was able to teach."

In response to the question of "Would you recommend your friends join the next class of the program?", twelve students (92\%) answered positively and reasoned: "Because the program teaches, contributes on a personal level, and is also full of experiences - all in one". One student $(8 \%)$ replied that he would reservedly recommend it as the practical part did not go well administratively at the high school in which he had chosen to teach.

Students' motivational factors at the end of the program are summarized in Table II. The ways in which the program has satisfied students' needs are presented in Table III.

TABLE II.

STUDENTS' MOTIVATIONAL FACTORS (END OF PROGRAM)

\begin{tabular}{|l|l|l|}
\hline \multicolumn{1}{|c|}{$\begin{array}{c}\text { Motivational } \\
\text { factor }\end{array}$} & \multicolumn{1}{|c|}{ Example } & \multicolumn{1}{c|}{ Interpretation } \\
\hline $\begin{array}{l}\text { Intrinsic motiva- } \\
\text { tion }\end{array}$ & $\begin{array}{l}\text { This is the most fun } \\
\text { thing I have had since I } \\
\text { started studying at the } \\
\text { Technion. (Question- } \\
\text { naire) }\end{array}$ & $\begin{array}{l}\text { The program was enjoy- } \\
\text { able }\end{array}$ \\
\hline $\begin{array}{l}\text { Extrinsic motiva- } \\
\text { tion / Identified } \\
\text { regulation }\end{array}$ & $\begin{array}{l}\text { I learned how to im- } \\
\text { prove my teaching } \\
\text { skills... it benefited me. } \\
\text { (Questionnaire) }\end{array}$ & $\begin{array}{l}\text { The program was benefi- } \\
\text { cial since it was able to } \\
\text { provide teaching skills }\end{array}$ \\
\hline
\end{tabular}

TABLE III.

FULFILLMENT OF STUDENTS' NEEDS (END OF PROGRAM)

\begin{tabular}{|c|l|l|}
\hline Need & \multicolumn{1}{|c|}{ Example } & \multicolumn{1}{|c|}{ Interpretation } \\
\hline Competence & $\begin{array}{l}\text { My self-confidence im- } \\
\text { proved really rapidly... I felt } \\
\text { wonderful that I was able to } \\
\text { teach. (Interview) }\end{array}$ & $\begin{array}{l}\text { The need for compe- } \\
\text { tence was fulfilled by } \\
\text { successfully accom- } \\
\text { plishing the challenge } \\
\text { of teaching a class }\end{array}$ \\
\hline Autonomy & $\begin{array}{l}\text { A really fun experience... } \\
\text { there is no other place - } \\
\text { school or academic course - } \\
\text { which gives you such a free } \\
\text { hand as they do here... } \\
\text { which lets you try and } \\
\text { dare... make your own } \\
\text { decisions regarding what to } \\
\text { teach, how, and at what } \\
\text { pace. } \\
\text { (Interview) }\end{array}$ & $\begin{array}{l}\text { The need for autonomy } \\
\text { was satisfied with the } \\
\text { sense of a "free hand" } \\
\text { the students had felt } \\
\text { when determining their } \\
\text { high school teaching } \\
\text { subjects }\end{array}$ \\
\hline Relatedness & $\begin{array}{l}\text { This is the high school I had } \\
\text { attended... this is my com- } \\
\text { munity and I can help it. } \\
\text { (Questionnaire) }\end{array}$ & $\begin{array}{l}\text { The need for related- } \\
\text { ness was fulfilled by } \\
\text { school where the stu- } \\
\text { dents themselves had } \\
\text { studied and felt a sense } \\
\text { of belonging thereto }\end{array}$ \\
\hline
\end{tabular}


Fig. 1 presents the frequency of mentioning intrinsic motivational factors and extrinsic motivational factors which reflect identified regulation in the answers received in the different questionnaires. It is important to emphasize that other extrinsic motivational factors (or amotivation) were not found in the students' answers. The chart indicates that while the frequency of extrinsic factors which express identified regulation remained nearly fixed, the frequency of intrinsic factors considerably increased during the program.

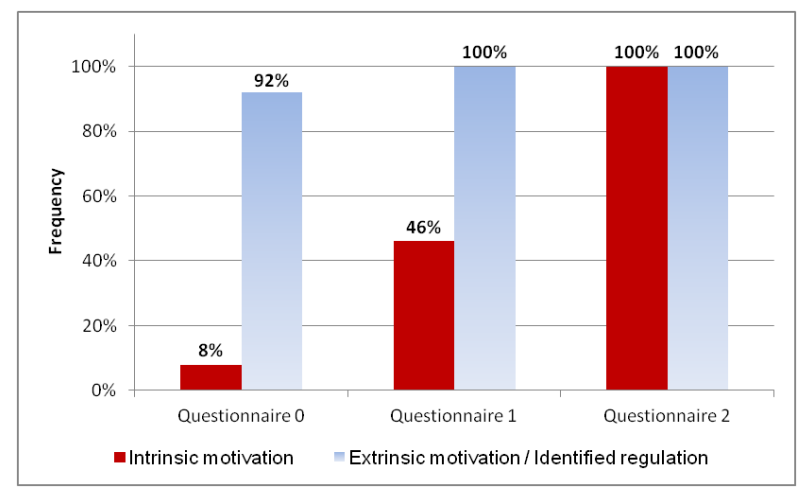

Figure 1. Intrinsic and extrinsic motivational factors: Frequency of mentioning in questionnaire answers

\section{DISCUSSION}

According to the findings, the weight of identified motivational factors was nearly unchanged throughout the program and maintained a very high value. This would indicate the students' expectations to benefit from the program - expectations which were expressed in their answers to Questionnaire 0 - were indeed met as can be seen from their answers to Questionnaires 1 and 2. However, a notable change in intrinsic motivation factors was evident during the program. In the beginning of the program the weight of intrinsic factors was very low compared with the weight of extrinsic factors. As the program progressed, the weight of intrinsic factors increased to the point where all students noted their interest in and enjoyment of the program.

The gradual improvement in intrinsic motivation can be explained in light of the self-determination theory [13-14]. According thereto, improvement is the result of the program's ability to satisfy the individual's three basic needs. The need for competence was fulfilled by successfully accomplishing the challenge of teaching a class; the need for autonomy was satisfied with the sense of a "free hand" the students had felt when determining their high school teaching subjects; and, finally, the need for relatedness was fulfilled by teaching at a high school where the students themselves had studied and felt a sense of belonging thereto. While the need for competence was beginning to be fulfilled already following their experience with microteaching at the Technion and continued to be fulfilled during their teaching at a high school, the two additional needs were satisfied only during their teaching at the high school.

The abovementioned results conform to the findings by [25-26] that show an improvement in the intrinsic motivation of engineering students who attended courses that have fulfilled these three needs. It is especially interesting to compare the results with those received at a study examining the motivation of engineering students who had demonstrated laboratory experiments at high schools in Brazil [6]. In this case as well the students' intrinsic motivation had improved, however for reasons which only partially overlap. In both cases the students had experienced a sense of being able to rise to the teaching challenge. In addition, the sense of autonomy was similar in both cases and was the result of the relative freedom the students received when teaching or demonstrating laboratory experiments in high schools. However, there is a difference regarding the third need, namely, relatedness. While in the current study satisfying the need of relatedness was the result of teaching at the high school where the student had studied and to which he/she felt he/she belonged, in the study described in [6], the need of relatedness was fulfilled by belonging to the unique group of students which was selected to take part in the program. Additionally, when comparing the abovementioned studies it is important to remember the significant difference between the two programs: the current program does not grant scholarships to students in return for their participation while the other program provides them.

The theoretical importance of the study is expressed by characterization, for the first time to the best of our knowledge, of motivational factors in this unique program. The practical contribution may be expressed by applying the findings when planning similar programs. These contributions are more valid in light of the severe shortages in scientist and engineers [1-2].

The current study was based on a relatively small population. In the follow-up study we intend to increase the number of students who participate in the program. Moreover, we intend to examine the attitudes of the high school pupils, their teachers and parents towards the program.

\section{SUMMARY}

The Technion - Israel Institute of Technology has initiated a unique program called "Educational Clinic", which trains engineering students as teaching assistants in high schools in order to help high school pupils with mathematics and science.

The study examined the motivation of thirteen students, who had participated in the first class of the program, throughout the year. The findings indicate that alongside a fixed high level of extrinsic motivational factors, which express student satisfaction of improving their teaching skills, a notable increase was found in the level of intrinsic motivational factors, which reflect the students' interest in the program.

\section{ACKNOWLEDGMENT}

The author expresses his thanks to Yotam Drechsler for his ideas and Orit Hazzan and Michal Seri for their great assistance in the design and execution of the program.

\section{REFERENCES}

[1] National Science Board, Science and engineering indicators 2010, Arlington, VA, National Science Foundation, 2010.

[2] I. Zeid, J. Chin, S. Kamarthi, and C. Duggan, "New approach to effective teaching of STEM courses in high schools," International Journal of Engineering Education, vol. 29, pp. 154-169, 2013. http://www.ijee.ie/latestissues/Vol29-1/15 ijee2678ns.pdf

[3] P. Molina-Gaudo, S. Baldassari, M. Villarroya-Gaudo, and E. Cerezo, "Perception and intention in relation to engineering: A gendered study based on a one-day outreach activity," IEEE Transactions on Education, vol. 53, pp. 61-70, 2010. http://dx.doi.org/10.1109/TE.2009.2023910 
[4] O. Hazzan, A. Tal, and I. Keidar, "Female pupils' perception of electrical engineering," in Encyclopedia of Gender and Information Technology, M. Trauth, Ed. 2006 , pp. 310-316.

[5] S. Coleman, A. Hinds, E. Nichols, and H. Sayers, "Improving first year retention in computer science by introducing programming in schools," in International Conference on Engineering Education 2012 - Proceedings, J. Björkqvist, M. Laakso, J. Roslöf, R. Tuohi, and S. Virtanen, Eds. Turku University of Applied Sciences, 2002, pp. 779-784.

[6] G. J. de Sena, M. A. A. Monteiro, L. Mesquita et al., "Engineering students involved in activities to motivate high school students for engineering courses," in International Conference on Engineering Education 2012 - Proceedings, J. Björkqvist, M. Laakso, J. Roslöf, R. Tuohi, and S. Virtanen, Eds. Turku University of Applied Sciences, 2002, pp. 1058-1064.

[7] M. L. Maehr, "Meaning and motivation: Towards a theory of personal investment", in Research on Motivation in Education, vol. 1, C. Ames and E. Ames, Eds. 1984, pp. 115-144.

[8] D. McClelland, The Achieving Society. Van Nostrand, 1961.

[9] B. F. Skinner, The Technology of Teaching. Appleton-CentauryCrofts, 1968.

[10] A. Bandura, "Self-Efficacy: Toward a unifying theory of behavioral change," Psychological Review, vol. 84, pp. 191-215, 1977. http://dx.doi.org/10.1037/0033-295X.84.2.191

[11] B. Weiner, An Attribution Theory of Motivation and Emotion. Springer-Verlag, 1986. http://dx.doi.org/10.1007/978-1-46124948-1

[12] A. Maslow, Motivation and Personality. Harper, 1954.

[13] E. L. Deci and R. M. Ryan, Intrinsic Motivation and Selfdetermination in Human Behavior. Plenum Publishing Co., 1985. http://dx.doi.org/10.1007/978-1-4899-2271-7

[14] E. L. Deci and R. M. Ryan, "The 'what' and 'why' of goal pursuits: Human needs and the self-determination of behavior," Psychological Inquiry, vol. 11, pp. 227-268, 2000. http://dx.doi.org/10.1207/ S15327965PLI1104 01

[15] J. G. Nicholls, "Achievement motivation: Conceptions of ability, subjective experience, task choice, and performance, "Psychological Review, vol. 91, 328-346, 1984. http://dx.doi.org/10.1037/ 0033-295X.91.3.328

[16] E. L. Deci, Intrinsic Motivation. Plenum, 1975. http://dx.doi.org/10.1007/978-1-4613-4446-9

[17] R. M. Ryan, "Psychological needs and the facilitation of integrative processes," Journal of Personality, vol. 63, 397-427, 1995. http://dx.doi.org/10.1111/j.1467-6494.1995.tb00501.x

[18] E. L. Deci, R. J. Vallerand, L.G. Pelletier, and R. M. Ryan, "Motivation and education: The self-determination perspective," Educational Psychologist, vol. 26, pp. 325-346, 1991. http://dx.doi.org/10.1080/00461520.1991.9653137

[19] R. M. Ryan and E. L. Deci, "Intrinsic and extrinsic motivations: Classic definitions and new directions," Contemporary Educa- tional Psychology, vol. 25, 54-67, 2000. http://dx.doi.org/10.1006/ ceps. 1999.1020

[20] W. C. Liu, C. K. Wang, O. S. Tan, J. Ee, and C. Koh, "A selfdetermination approach to understanding students' motivation in project work," Learning and Individual Differences, vol. 19, pp.139-145, 2009. http://dx.doi.org/10.1016/j.lindif.2008.07.002

[21] C. P. Niemiec and R. M. Ryan, "Autonomy, competence, and relatedness in the classroom: Applying self-determination theory to educational practice," Theory and Research in Education, vol. 7, pp. 133-144, 2009. http://dx.doi.org/10.1177/147787850 $\underline{9104318}$

[22] R. M. Ryan and E. L. Deci, "Promoting self-determined school engagement: Motivation, learning, and well-being," in K. R. Wentzel \& A. Wigfield (eds.), Handbook on Motivation at School. Routledge, 2009.

[23] C. S. Levesque, N. Zuehlke, L. Stanek, and R. M. Ryan, "Autonomy and competence in German and US university students: A comparative study based on self-determination theory," Journal of Educational Psychology, vol. 96, pp. 68-84, 2004. http://dx.doi.org/10.1037/0022-0663.96.1.68

[24] R. Kusurkar, G. Croiset, C. Kruitwagen, and O. ten Cate, "Validity evidence for the measurement of the strength of motivation for medical school," Advances in Health Science Education, vol. 16, pp. 183-195, 2011. http://dx.doi.org/10.1007/s10459-010-9253-4

[25] C. Koh, H. S. Tan, K. C. Tan, L. Fang, F. M. Fong, D. Kan, S. L. Lye, and M. L. Wee, "Investigating the effect of 3d simulationbased learning on the motivation and performance of engineering students," The Journal of Engineering Education, vol. 99, pp. 237251, 2010. http://dx.doi.org/10.1002/j.2168-9830.2010.tb01059.x

[26] A. Gero, "Improving intrinsic motivation among sophomore electrical engineering students by an introductory project," International Journal of Engineering Pedagogy, vol. 2(4), pp. 13-17, 2012. http://dx.doi.org/10.3991/ijep.v2i4.2247

\section{AUTHOR}

A. Gero holds a B.A. in physics, a B.Sc. in electrical engineering, an M.Sc. in electrical engineering, and a Ph.D. in theoretical physics, all from the Technion - Israel Institute of Technology. In addition, he has an MBA from the University of Haifa, Israel. He is a faculty member at the Department of Education in Technology and Science of the Technion (e-mail: gero@technion.ac.il). His research focuses on electrical engineering education and interdisciplinary education that combines physics with electronics, such as electro-optics and microelectronics education.

This work was supported by the Planning and Budgeting Committee of the Council for Higher Education of Israel. Submitted, January 1, 2014. Published as resubmitted by the author on June 15, 2014. 